\title{
HOW WILL THE USE OF TECHNOLOGY IN TRANSLATION AND TESTING AFFECT LANGUAGE LEARNING?
}

\author{
David Michael Bourne \\ English Department, Faculty of Humanities, Bina Nusantara University \\ Jln. Kemanggisan Ilir III, No. 45, Kemanggisan - Palmerah, Jakarta Barat 11480 \\ dbourne@binus.edu
}

\begin{abstract}
Technology has an ever increasing impact on how we work and live. Article adressed the issue of the impact of technology in two key areas of language learning. On the one side learners increasingly used technology to translate. Given this trend, was there any real need to learn a language. On the other side, educational institutions increasingly used technology to rate language proficiency. Given this trend, would the work of the teacher become less and less important. The survey was conducted by using quantitative method. The respondents' age range was 18-25. There were 53 respondents, $35 \%$ were male and $65 \%$ were female. The instrument was a questionaire having 9 questions describing the students' reliance on computer in translation. It can be concluded that learners of English indicate that they accept and welcome the role of technology in language learning, but there is a doubt that the role and participation of humans in the learning process will be completely replaced. The human element remains an important ingredient. (EE)
\end{abstract}

Keywords: technology use, translation, testing effect, language learning

\begin{abstract}
ABSTRAK
Dampak teknologi makin meningkat di dalam pekerjaan dan kehidupan manusia. Artikel menggambarkan dampak teknologi terhadap dua masalah yang berbeda di bidang pembelajaran bahasa. Pada satu sisi, pembelajar makin meningkat dalam menggunakan teknologi pada tugas penerjemahan. Dalam hal ini, apakah ada keinginan yang mendasar untuk belajar suatu bahasa. Di pihak lain, institusi pendidikan menggunakan teknologi untuk menilai kemampuan berbahasa. Dalam kasus ini, apakah tugas guru menjadi makin sedikit dan tidak penting. Penelitian menggunakan metode kuantitatif dengan 53 responden dari mahasiswa jurusan Sastra dan Budaya Inggris dari suatu universitas swasta di Jakarta. Instrumen penelitian menggunakan kuesioner dengan 9 pertanyaan yang menggambarkan ketergantungan mahasiswa terhadap komputer dalam penerjemahan bahasa. Disimpulkan, mahasiswa bisa menerima peran teknologi dalam pembelajaran bahasa walaupun terdapat juga kekhawatiran bahwa teknologi akan menggantikan peran manusia di dalam proses pembelajaran bahasa. Diharapkan, peran manusia tetap dominan di dalam pembelajaran bahasa, bukan teknologi. (EE)
\end{abstract}

Kata kunci: penggunaan teknologi, penerjemahan, dampak penilaian, pembelajaran bahasa 


\section{INTRODUCTION}

Article considers how the language teaching profession is affected by automation. Article looks at the increasing role of technology in translation and testing and identifies the strengths and weaknesses of how this technology is applied. It will also present the views of some learners with relation to how they use technology in language learning.

It almost seems too obvious to state that computer technology has had a profound effect on how we live our lives. The digital age has affected how we communicate, what we know, and how we use our free time. In fact, social media has been attributed as one of the important catalysts for the social and political changes affecting the whole country of Egypt and beyond. Technology has no less impact on the world of work. Many jobs that were done by humans in earlier decades have already been replaced by technology. Technology is likely to take more jobs in the future. Pink (2005) makes the statement:

"To survive in this age, individuals and organizations must examine what they're doing to earn a living and ask themselves three questions: (1) can someone overseas do it cheaper? (2) can a computer do it faster? and (3) is what I'm offering in demand in an age of abundance?"

Pink (2005) also addresses the problem faced in the US of skilled jobs being taken through outsourcing. Pink (2005) states: "Outsourcing is overhyped in the short term. But it's underhyped in the long term." Technology is the one of the key enablers of outsourcing. For example, it allows companies to scan, say, documents, send them anywhere in the world through a secure Internet channel to be analyzed by accountants in India. However, the recent trend of outsourcing is only a step towards automation. Even work that is outsourced may be replaced by a computer: "Last century, machines proved they could replace human backs. This century, new technologies are proving they can replace human left brains," says Pink (2005).

Most of us are aware of and comment on the fact that our world is speeding up. Laptop computers are becoming more and more powerful, with software applications that offer more and more capabilities. The speed of change is often summarized by Moore's "law". Gordon E. Moore was the co-founder of Intel Corporation. In 1965, he commented, "As technology progresses, the computational capability of a computer will roughly double every two years" (Ford, 2009:29).

Ford (ibid.) claims that Moore's law is, "an accurate observation and projection, and nearly everyone in the technology field accepts it." If we assume that Moore's law is an accurate estimation of the rate of technological change, this exponential growth could have profound effects. Some people might contend that this rate of growth is unsustainable over an extended period of time. Physical restrictions are likely to hinder progress. Ford (2009:3839) answers, "If the pace fell off so that doubling took four years (or even longer) rather than the current two years, that would still be an exponential progression that would bring about staggering future gains in computing power." Any job that depends on routines - that can be reduced to a set of rules, or broken down into a set of repeatable steps - is at risk. Based on this prediction, automation could affect all kinds of professions, including teachers.

The January 18, 2014 lead article in the Economist addresses the problems and opportunities related to technology and jobs. Technological progress offers benefits. These benefits, or innovations, include the introduction of new and exciting products (e.g. smart phones, tablet computers) that allow us to do new things and experience new kinds of entertainment. The benefits also include new job opportunities such as computer programmers and web designers. However, the Economist (2014, January 18) also argues that such progress will have a serious impact on the availability of jobs, and that governments are nowhere near prepared to cope with this change. In line with the comments above related to Moore's Law, the Economist writes:

"Until now jobs most vulnerable to machines were those that involved routine, repetitive tasks. But thanks to the exponential rise in processing power and the ubiquity of digitized information ("big data"), computers are increasingly able to perform complicated tasks more cheaply and effectively than people." (The Economist, 2014)

The same article goes so far as to reference an Oxford University study which expects $47 \%$ of today's jobs to be automated in the next two decades.

Natural language Processing is not to be confused with Neuro-Linguistic Processing. As is common in these matters, no single definition is unanimously accepted, but NLP refers to the use of technology to analyze authentic texts. The idea is for machines to reach the same processing capabilities as humans. If machines are able to process language in the same way that humans do, a wide range of tasks may be achieved. For example, NLP would allow humans to give verbal instructions to machines, such as telling one's car to start, or instructing your computer to play a favourite song.

Liddy (2001) identifies four main capabilities for NLP. They are (1) to paraphrase an input text; (2) to translate text into another language; 3 ) to answer questions about the contents of a text; and 4) to draw inferences from the text. According to Liddy (2001) great progress has been made with the first three competencies, but the fourth remains elusive. Part of the reason for this lies in the nature of language itself. Language is processed at various levels. These levels include the phonological level (for speaking), the morphological level, the lexical, syntactic, semantic, discourse, and pragmatic levels. Since the lower levels, such as morphemes, words and sentences are smaller units and are rule govered, they are easier to be researched and analysed by the computer. Higher levels deal with aspects such as world knowledge and are not predictably rule governed. For example, at the pragmatic level, analysis has to consider what is meant beyond just an utterance or a written sentence.

The challenges faced by NLP can perhaps be 
summed by Bryson (1990), who happily describes the complex web of English:

As native speakers we seldom stop to think just how complicated and illogical English is... What, for instance, is the hem in hem and haw, the shrift in short shrift, the fell in one fell swoop? When you are overwhelmed, what is the whelm you are over, and what exactly does it look like? And why, come to that, can we be overwhelmed or underwhelmed but not semi whelmed" (Bryson, 1990)

Various approaches to NLP are currently being adopted. They have similarities and differences, so different approaches are more effective at different tasks. In fact researchers, according to Liddy (op.cit.), are developing hybrid versions of these approaches. The main point is that NLP developments have a direct impact on the way a language learner uses technology to communicate. For example, key application of NLP is that of Machine Translation (MT) which is discussed below.

Automatic, accurate and realistic translation of languages by computers can have a resounding impact on language teaching. If it becomes possible for a piece of software or application to faithfully translate English, then the need to master a foreign language becomes less and less important. If we reach a point where a person can type or speak a text into an application on their mobile device, which will faithfully translate the text into English, then there really is no need to learn English.

Crystal (2006) writes that such an innovation would have a two-fold effect, firstly on the status of English as a global lingua franca, and secondly that it would undermine the need for a person to learn a foreign language at all. Crystal (2006) is somewhat cautious about when this will happen, however:

"Such a world is, of course, a very long way off. Only a tiny number of languages are seen to be commercially viable prospects for automatic translation research, and few of the world's languages have attracted linguistic research of the magnitude required to make machine translation viable. The issue is, accordingly, only of theoretical interest - for now."

As discussed, certainly the complexities of translating, or processing English offer major challenges to the computer programmers. A translator, whether human or computer needs to understand language at several different levels, including, the appropriate meaning of words, the words in a sentence and how they interact grammatically and lexically to convey meaning, as well as the situations and contexts in which texts are created.

Nevertheless, technology has clearly had a significant impact on the translation world. Translators make the distinction between Machine Translation (MT), which refers to translation by a machine (i.e. computer) without human intervention. Such translation, according to Craciuneescu, Gerding-Salas, and Stringer-O'Keefe (2004), relies on 'huge plurilingual dictionaries, as well as corpora of texts'. Computer Assisted Translation (CAT) offers the human translator technological tools that can be used to aid translation. Such tools include terminology databases and translation memories.

The consensus among translators would appear to accept the fact that use of technological tools is inevitable and has become an integral part of the work of a translator. However, it seems that most translators still see the role of a human being as paramount:

"It is important to stress that automatic translation systems are not yet capable of producing an immediately usable text, as languages are highly dependant on context and on the different denotations and connotations of words and word combinations. It is not always possible to provide full context within the text itself, so that machine translation is limited to concrete situations and is considered to be primarily as a means of saving time, rather than a replacement for human activity." (Craciuneescu et.al., 2004)

Stupiello (2008) discusses the effect of technology in translation and echoes the ideas proffered by Craciuneescu, Gerding-Salas, \& Stringer-O'Keefe (2004). Stupiello (2008) writes that the translator is increasingly taking the role of editor to the initial computer generated translation. Stupiello's concern is that the work of the human translator fades into the background as readers associate the final product with that of the machine, rather than the translator. Stupiello (2008) concludes, "The illusion is that the machine is able to translate may affect the way translators will be seen in the future, an impression that should be given careful consideration" (Stupiello, 2008).

Despite some reservations regarding machine translation,Zetzsche(2010) accepts that this development is part of life. Zetzsche (2010) gives a long list of applications that perform this task: SDL Trados, Wordfast, Across, memoQ, Alchemy, Publisher, MetaTexis, MultiTrans and Google Translator toolkit. These applications have connectors with Google Translate, and other engines, most notably Bing Translator and Yahoo BabelFish.

Zetzsche (2010) asked the readers of his newsletter whethermachine translators represented arealimprovement to their work. As might be expected, there were a number of opposing opinions, with some satisfied with their use of machine translation and others not. The key concern was that the machine translator was appropriately trained to handle the genre of text that was to be input.

Technological developments in machine translation is one area that could impact the need for learners to learn a second language, and therefore whether they need a teacher to help them in their learning. Another important area is that of automated marking systems. These systems share similar features to machine translators in their design.

Computer technology offers some enticing general benefits in language testing. The first benefit is that technology calculates results instantly. In addition, the computer will always rate in the same way. Its 'actions' are predictable. Another benefit is that the data created can be presented in many different ways and at an intriguing 
level of specificity. For example, the computer can easily tell how many people chose option ' $A$ ' in a particular multiple choice question, and it can produce the standard scores over a whole range of test questions. This produces a much wider range of information about the test. The computer can also control the time that a learner has to complete the test. Finally, of course, the computer is much cheaper than paying a human being.

One of the key areas in which computers might affect the work of a teacher is in essay rating. Perhaps not surprisingly this is a highly active market, with many software companies competing to gain access to what could be an extremely lucrative market. For example, a Financial Times article estimated the size of the US educational consulting industry to have earned a revenue of $\$ 15.4$ bn in 2011 , with an annual growth rate of $5 \%$ anticipated in the next 5 years.

There are a number of clear advantages to using robot marking systems. Most notably, time and financial savings are clearly attractive, "Grading tests, particularly written responses, requires labour that publicly funded school systems have to pay for out of tightening budgets" (Mishkin, 2012).

Williamson, Bennett, Lazer, Bernstein, et al (2010) write that human graders entail the problems of expense, the lengthy amount of time involved in producing grades and limitations to objective and consistent marking among human graders.

Back in 2009, the Guardian cited Tim Oates, a director of research for Cambridge assessment," "It's extremely unlikely that automated systems will not be deployed extensively in educational assessment" (Curtis, 2009).

More recently, the media in Australia report on the inevitability of robots. The Herald Sun newspaper (2012, May 2) describes the latest computer software that achieved very close ratings with those of humans over 16,000 essays. The newspaper's headline states,"Computers will take over marking university and high school essays from tutors and teachers within a few years, researchers claim" (The Herald Sun, 2012).

From a more academic perspective, Chapelle and Douglas (2006) identify the importance of language tests delivered by computers, "Many high and low stakes tests are delivered by computer and the number is increasing."

A common use of computers is to provide Computer Adaptive Tests(CATs). These tests involve a large collection of data and questions. The questions asked depend on the user's response to the previous question, with subsequent questions becoming easier or more difficult, depending on whether the previous question has been answered correctly or not. A commercial example of such a test would be the Oxford Placement test, which is an online diagnostic test that is intended to place users according to the European framework of English proficiency. Chapelle and Douglas (ibid) identify a further advantage of CATs, "CATs are efficient because they present items to test takers close to their level of ability."

The multimedia capabilities of computers also offer several advantages in that they can aid authenticity. Visual and audio input allows test takers to access meaning from various features of context such as setting, participants, content, tone and genre. As such, multi media test tasks delivered through technology allow us to measure a learner's comprehension and performance in more realistic situations. Increases in the power of technology have made it much easier to produce multimedia content.

One well known application used to rate essays is 'e-rater', developed by ETS. This automated essay scoring application is used to rate high stakes tests administered by ETS, such as TOEFL and GMAT. In a paper that describes the e-rated V.2, Attali and Burstein (2006) ague, "Results show that e-rater scores are are significantly more reliable than human scores and that the true score correlation between human and e-rater scores is close to perfect."

Attali and Burnstein (2006) write that in assessing the performance of e-rater (or any other automated marking system), a comparison of the computer performance against a human performance is not enough. Many studies have looked at this issue, but there are additional criteria for measurement. For example, it is important to take account of how reliable raters are between tasks. To illustrate, if a student writes two essays in response to two different tasks, a reliable rater should rate both essays accurately. Attali and Burstein (ibid) write that e-rater demonstrates accuracy in this area, "The machine scores, on the other hand, have perfect inter-rater reliability. All this suggests that it might be better to evaluate automated scores on the basis of multiple essay scores."

In their paper, Attali and Burstein (2006) hint at an increased role for e-rater. They suggest that the application allows for greater standardization, where a single approach can be used to accurately rate a variety of written tasks, and provide specific feedback on features where writing is weak. If Moore's law holds true, the accuracy of computer marking systems is only going to increase as computers become more able to process all the complicated nuances of language.

It should be noted that despite the enthusiastic claims of newspaper reports, there are concerns over computerized marking systems. The Guardian quotes John Bangs from the National Union of teachers in the UK, who worries that questions will become narrower to accommodate the computer. This viewis perhaps not surprising, though, since it is the view of a union representative who would presumably be interested in protecting teachers' jobs. However, this concern is also alluded to by ETS in Williamson, Bennett, Lazer, Bernstein, et al's (2010) report, which admits that the degree of predictability is a factor that influences the efficacy of computer raters. The more predictable an answer is, the easier it is for a computer to rate. Essay questions that involve communicating opinions and creative responses do not work well:

"Assessment of creativity, poetry, irony or other more artistic uses of writing is beyond such systems. They are also not good at assessing rhetorical voice, the logic of an argument, the extent to which particular concepts are accurately described, or whether specific ideas presented in the essay are well founded." (Williamson, Bennett, Lazer, Bernstein, et al, 2010). 
In fact one academic skeptical of robot markers was given access to the e-rater used by ETS. The New York Times (Winerip, 2012) quotes Mr. Les Perelman, who tested the e-rater. He decided that:

"...the automated reader can be easily gamed, is vulnerable to test prep, sets a very limited and rigid standard for what good writing is, and will pressure teachers to dumb down writing instruction. ... once you understand e-rater's biases, he said, it's not hard to raise your score." (Winerip, 2012)

One of the main challenges in developing computer based tests is developing the construct, or deciding what should be tested. Chapelle and Douglas (2006) comment," In other words, the construct, or meaning, of "writing ability" as defined by criterion is derived from features of the essay that the computer is able to recognize: content vocabulary, discourse markers, and certain syntactic categories."

Another notable consideration regarding computer tests is that the way in which the test is delivered could have an influence on performance, both positive and negative. As an example, the Internet based TOEFL test requires the candidate to talk on a topic. Since the test is internet based, the candidate talks directly to a computer using a microphone. This method may be compared to the IELTS speaking test, which is based on direct face to face interaction between two humans. It is also relevant to recognize that setting can also influence test performance. Given the flexibility of mobile devices and the ubiquity of wifi, a test taker can potentially take a test anywhere they like, and the setting may well impact performance. For example, a student taking a test in her favourite coffee shop while she is having a break with her friends may not perform as well as another student who goes to a study booth in the university library. Test designers therefore need to pay careful thought to ways in which they will control the test taking situation.

Although a very enticing advantage of computer based testing is that the test can be taken at any time and place that is most convenient to the user, one significant obstacle to realizing this particular advantage is that of identity. Needless to say, in a high stakes test it is essential to clearly determine that the test taker is who he says he is. If a computer test only relies on accepting passwords to represent the test taker, the security of the test becomes easily compromised, with imposters, or 'jockies', representing the real test taker. In February 2013 the BBC investigative documentary 'Panorama' reported widespread fraudulent activity regarding the TOEIC test, where test candidates were given answers and replaced by highly competent test takers. The undercover students subsequently achieved high scores that they could use for student visa applications. ETS, the company that owns TOEIC, has subsequently been suspended from the Home Office's list of approved English test providers.

\section{METHOD}

A survey was conducted in order to discover how learners view the importance of technology in language learning. The survey was completed by university students in the undergraduate programme in English literature and culture of a private university in Indonesia. The respondents' age range was 18-25. There were 53 respondent, $35 \%$ were male and $65 \%$ were female.

\section{RESULTS AND DISCUSSION}

The results of the survey are described in Table 1 . Meanwhile, Figure 1 shows the diagram of the result.

Table 1 The Results of the Survey

\begin{tabular}{|c|c|c|c|c|c|c|}
\hline & & 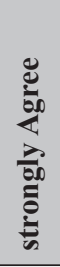 & 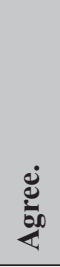 & 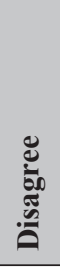 & 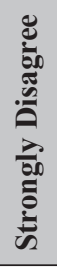 & 통 \\
\hline 1 & I use an online translation tool. & 12 & 34 & 5 & 2 & 53 \\
\hline 2 & Computer translation is accurate. & 1 & 22 & 27 & 3 & 53 \\
\hline 3 & Computers help me to learn English. & 22 & 28 & 1 & 1 & 52 \\
\hline 4 & You do not need a teacher to learn English; you can use a com- & 2 & 2 & 30 & 18 & 52 \\
\hline 5 & puter. & 2 & 14 & 32 & 4 & 52 \\
\hline 6 & I am comfortable speaking English to a computer. & 1 & 27 & 22 & 0 & 50 \\
\hline 7 & Computers are good at marking essays. & 6 & 34 & 12 & 1 & 53 \\
\hline 8 & $\begin{array}{l}\text { There will be a time when computers can translate anything we } \\
\text { want. }\end{array}$ & 0 & 1 & 25 & 27 & 53 \\
\hline \multirow[t]{2}{*}{9} & $\begin{array}{l}\text { We will not need to study languages because computers will } \\
\text { translate everything for us. }\end{array}$ & 3 & 29 & 20 & 1 & 53 \\
\hline & Computers are the future of language learning. & & & & & \\
\hline
\end{tabular}




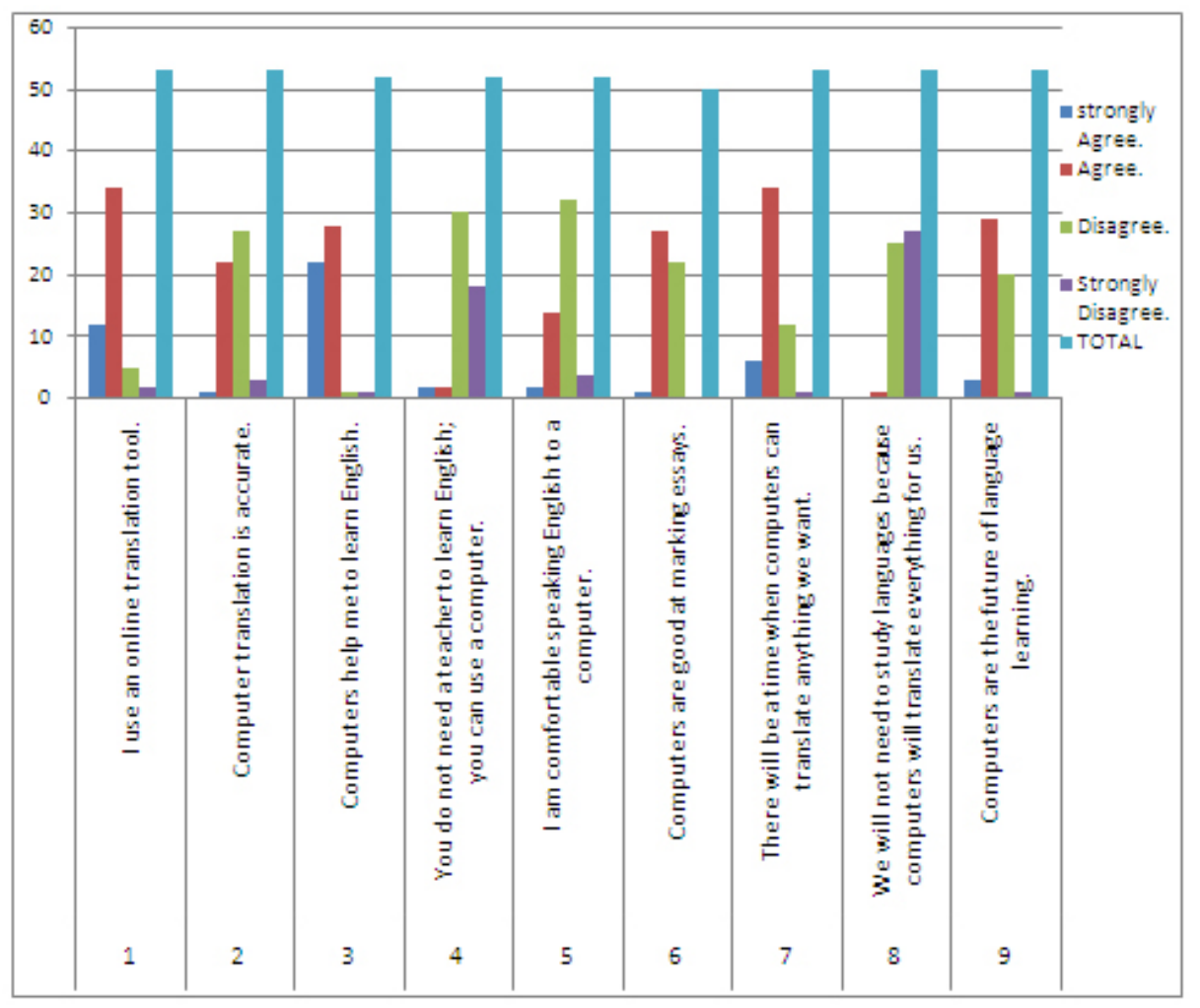

Figure 1 The Result of the Research

Figure 1 shows that the survey reveals ambivalent attitudes towards the role of technology in learning languages. For example, respondants generally used online translation tools. However the group were mixed about the efficacy of such tools, with a larger number tending to feel that online translation lacked accuracy. However, in contrast, most respondants agreed that, in the future, MT would be able to translate anything. With relation to technology in testing, there were mixed feelings about how computers can mark essays, although a majority agreed with the proposition.

The respondants' ambivalence is highlighted concerning their attitudes towards the role of technology in language learning. Nearly all students agreed that computers are an aid to learning English, and that they will play a significant role in the future. However, respondants seemed reluctant to let go of the human touch. The majority disagreed that only a computer is needed for learning a language. There was additional disagreement that technology would undercut the need to learn a language.

\section{CONCLUSION}

Article has considered the speed of technological development and how this might influence the language teaching profession. The paper considered how technology impacts the field of translation and automated testing. Technology has not yet mastered the art of translation, and consequently usurped the need for a person to actually learn a language. Automated essay or test scoring appears to be more and more likely in the future. It therefore appears that the work of a human teacher will be ever more entwined with technology.

Learners of English indicate that they accept and welcome the role of technology in language learning, but there is doubt that the role and participation of humans in the learning process will be completely replaced. The human elemant remains an important ingredient.

\section{REFERENCES}

Attali, Y. \& Burstein, J. (2006). Automated essay scoring with e-rater ${ }^{\circledR}$ V.2. Journal of Technology, Learning and Assessment, 4(3).

Bryson, B. (1990). The Mother Tongue. English and How It Got that Way. New York: Harper Collins.

Chappelle, C. \& Douglas, D. (2006). Assessing Language Through Computer Technology. Cambridge: Cambridge University Press.

Craciunescu, O., Gerding-Salas, C., \& Stringer-O'Keefe, S. (2004). Machine translation and

computer-assisted translation: a new way of translating? Translation Journal, 8(3).

Crystal, D. (2006). Language and the Internet. 2nd Ed. Cambridge: Cambridge University Press.

Curtis, P. (2009, September 25). Robot Computer Systems to mark English Essays. Retrieved Dec 122012 from http://www.theguardian.com/education/2009/ sep/25/robots-to-mark-english-essays.

Ford, M. (2009). The Lights in The Tunnel. US: Acculent. Liddy, E. D. (2001). Natural Language Processing. In Encyclopedia of Library and Information Science. 2nd Ed. NY: Marcel Decker. 
Mishkin, S. (2012, April 19). Can essay-marking software pass the test? Retrieved Dec 12, 2012 from http:// www.ft.com/intl/cms/s/0/f8924a5a-88aa-11e1a526-00144feab49a.html\#axzz3LwIlMcUJ

Pink, D. (2005). A Whole New Mind. New York: Routledge.

Stupiello, E. (2008). Ethical implications of translation technologies. Translation Journal, 12(1).

The Economist. (January 18, 2014). Coming to an Office near You. Retrieved from http://www.economist. com/news/leaders/21594298-effect-todaystechnology-tomorrows-jobs-will-be-immenseandno-country-ready

The Herald Sun. (2012, May 2). Who Needs Teachers when Computers Can Do the Job? Retrieved Dec, 122012.

Williamson, D. M., Bennett, R. E., Lazer, S., Bernstein, J. et al. (2010). Automated Scoring for the Assessment of Common Core Standards. New Jersey: Pearson-Education Testing Service. Available: https://www.ets.org/s/commonassessments/pdf/ AutomatedScoringAssessCommonCoreStandards. pdf

Winerip, M. (2012, April 22). Facing a Robo-Grader? Just Keep Obfuscating Mellifluously. Retrieved from http://www.nytimes.com/2012/04/23/ education/robo-readers-used-to-grade-test-essays. html?pagewanted $=$ all

Zetzsche, J. (2010). Hostile takeover? Welcome addition? Machine translation enters the world of the translator. Translation Journal, 14(3). 